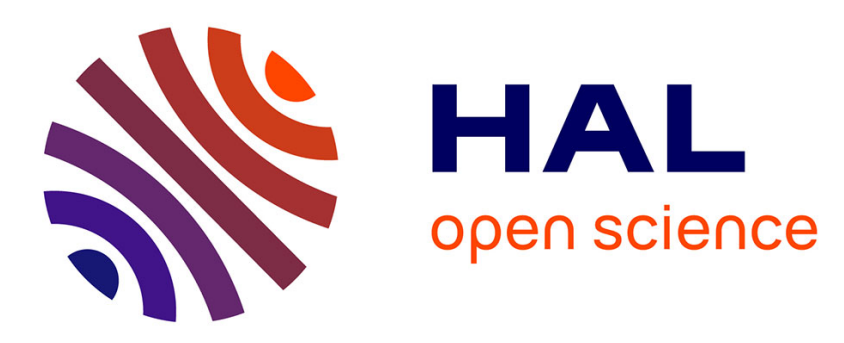

\title{
Mathematical modeling of differential effects of neo-adjuvant Sunitinib on primary tumor and metastatic growth
}

Chiara Nicolò, Michalis Mastri, Amanda Tracz, John M.L. Ebos, Sébastien Benzekry

\section{To cite this version:}

Chiara Nicolò, Michalis Mastri, Amanda Tracz, John M.L. Ebos, Sébastien Benzekry. Mathematical modeling of differential effects of neo-adjuvant Sunitinib on primary tumor and metastatic growth. AACR Annual Meeting 2018, Apr 2018, Chicago, United States. 78 (13 Supplement), pp.4264, 2018, 10.1158/1538-7445.AM2018-4264 . hal-01968917

\section{HAL Id: hal-01968917 \\ https://inria.hal.science/hal-01968917}

Submitted on 8 Jan 2019

HAL is a multi-disciplinary open access archive for the deposit and dissemination of scientific research documents, whether they are published or not. The documents may come from teaching and research institutions in France or abroad, or from public or private research centers.
L'archive ouverte pluridisciplinaire HAL, est destinée au dépôt et à la diffusion de documents scientifiques de niveau recherche, publiés ou non, émanant des établissements d'enseignement et de recherche français ou étrangers, des laboratoires publics ou privés. 


\section{Nicolò̀', M. Mastri2', A. Tracz'2, J. ML Ebos², S. Benzekry'}

1 Inria team MONC, Institut de Mathematiques de Bordeaux, Bordeaux, France.

2 Department of Cancer Genetics and Medicine, Roswell Park Cancer Institute, Buffalo, New York.

\section{BACKGROUND}

- Sunitinib is a drug with anti-angiogenic activity used in the treatment of patients with metastases from renal cell carcinoma or gastrointestinal tumors

- It is currently evaluated in clinical trials in the neo-adjuvant setting.

- Despite clear efficacy in reducing established tumor growth, recent preclinical studies have shown limited, or even opposing, efficacies in preventing metastatic spread.

- In this work, we evaluated a mathematical model of the metastatic process to describe primary tumor and metastatic dynamics in response to sunitinib in a clinically relevant ortho-surgical mouse model of spontaneous metastatic breast cancer.

\section{EXPERIMENTAL DATA}

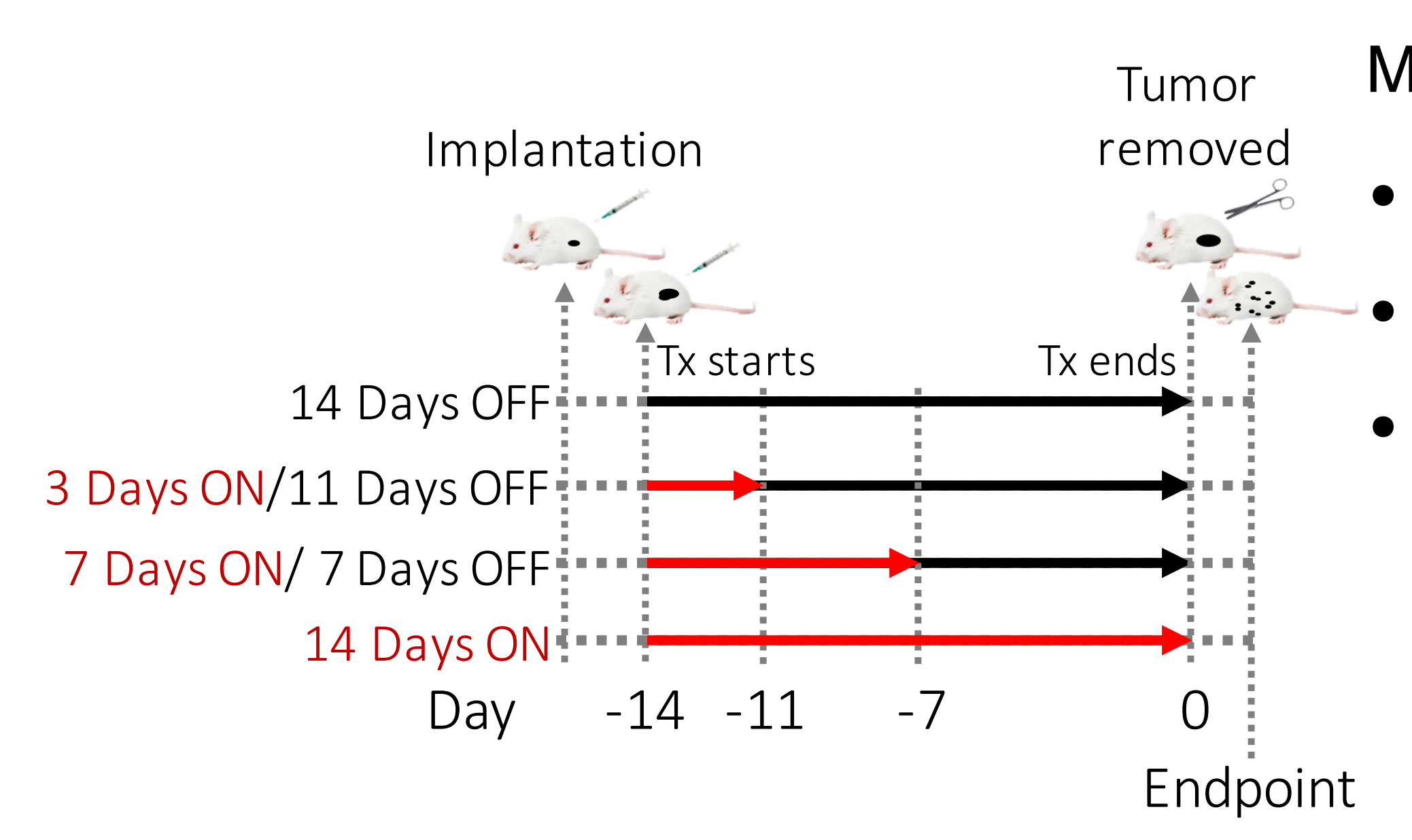

$\longrightarrow$ Vehicle $\longrightarrow$ Sunitinib [60mg/kg/day]

Orthotopic xenograft breast model: LM2-4LUC+ human metastatic breast carcinoma cells.

\section{Measurements of}

primary tumor kinetics,

metastatic burden (bioluminescence)

- pre-surgical molecular and cellular biomarkers, including Ki67 and CD31 expression, circulating tumor cells (CTCs) and myeloid derived suppressor cells (MDSCs).

Bioluminescence monitoring of postsurgical metastasis

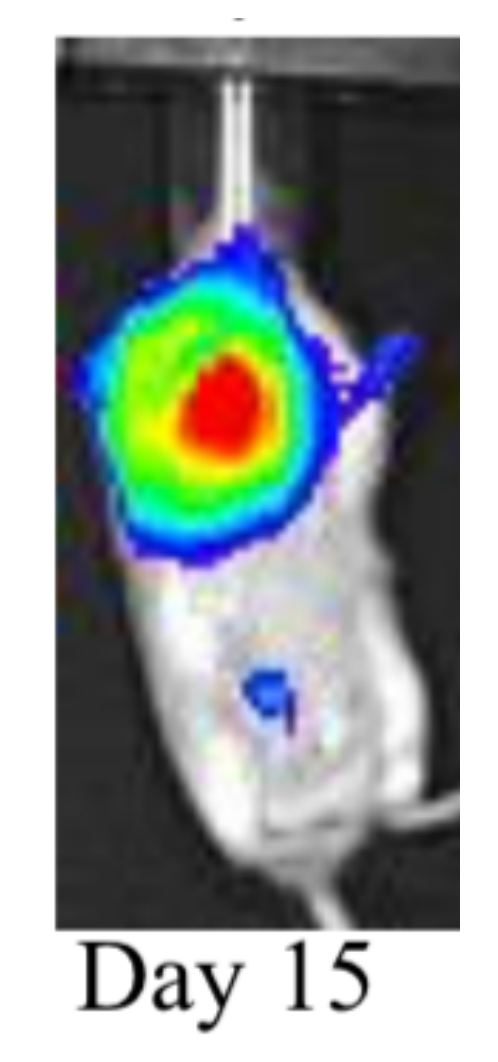

AN ELEMENTARY THEORY OF METASTATIC DYNAMICS:

\section{DISSEMINATION + GROWTH}

DIFFERENTIAL EFFECTS OF SUNITINB ON PRIMARY TUMOR AND METASTASIS

Primary tumor growth:
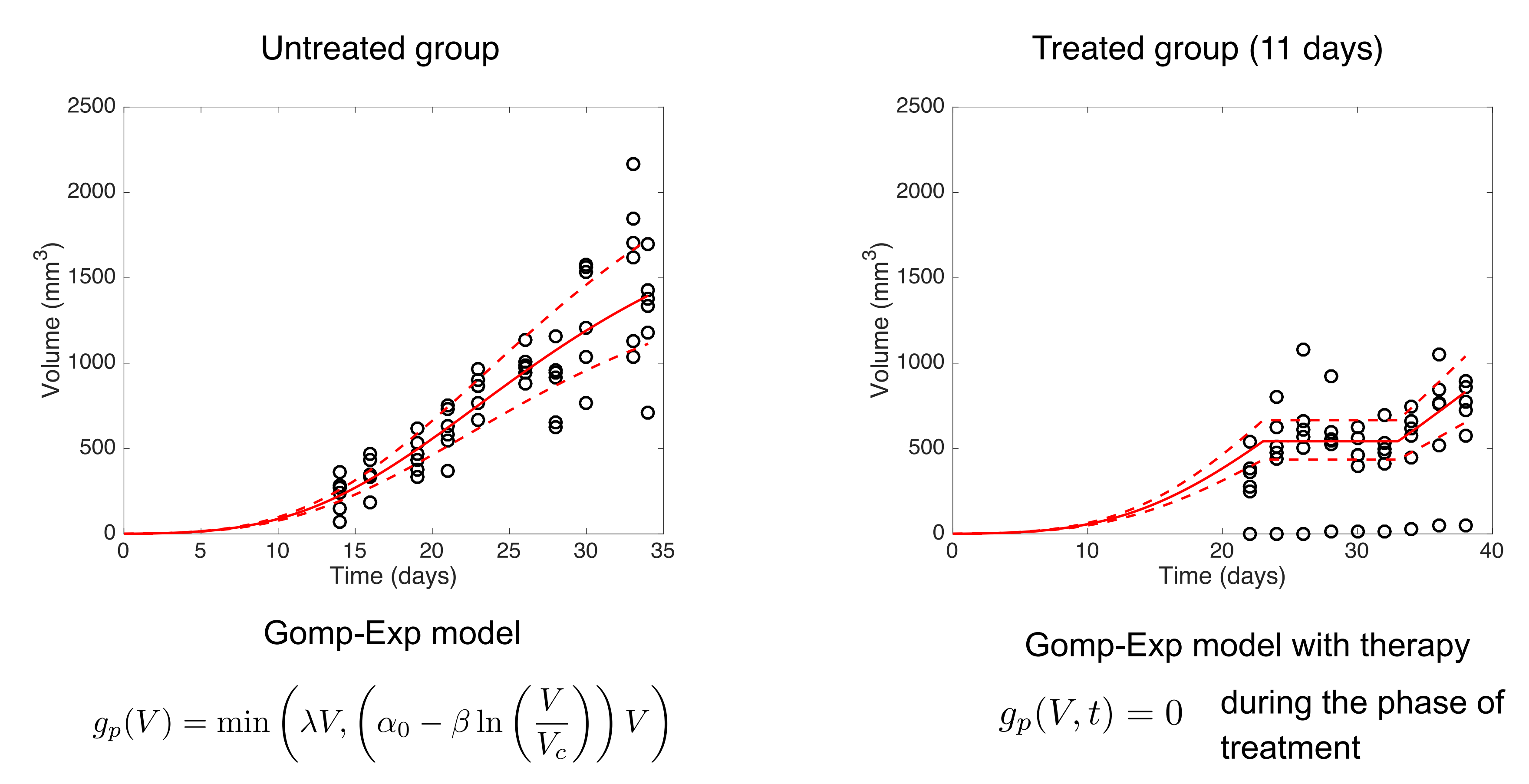

Gomp-Exp model with therapy $g_{p}(V, t)=0 \quad$ during the phase of treatment

Primary tumor - metastatic growth dynamics: Treated group (11 days)

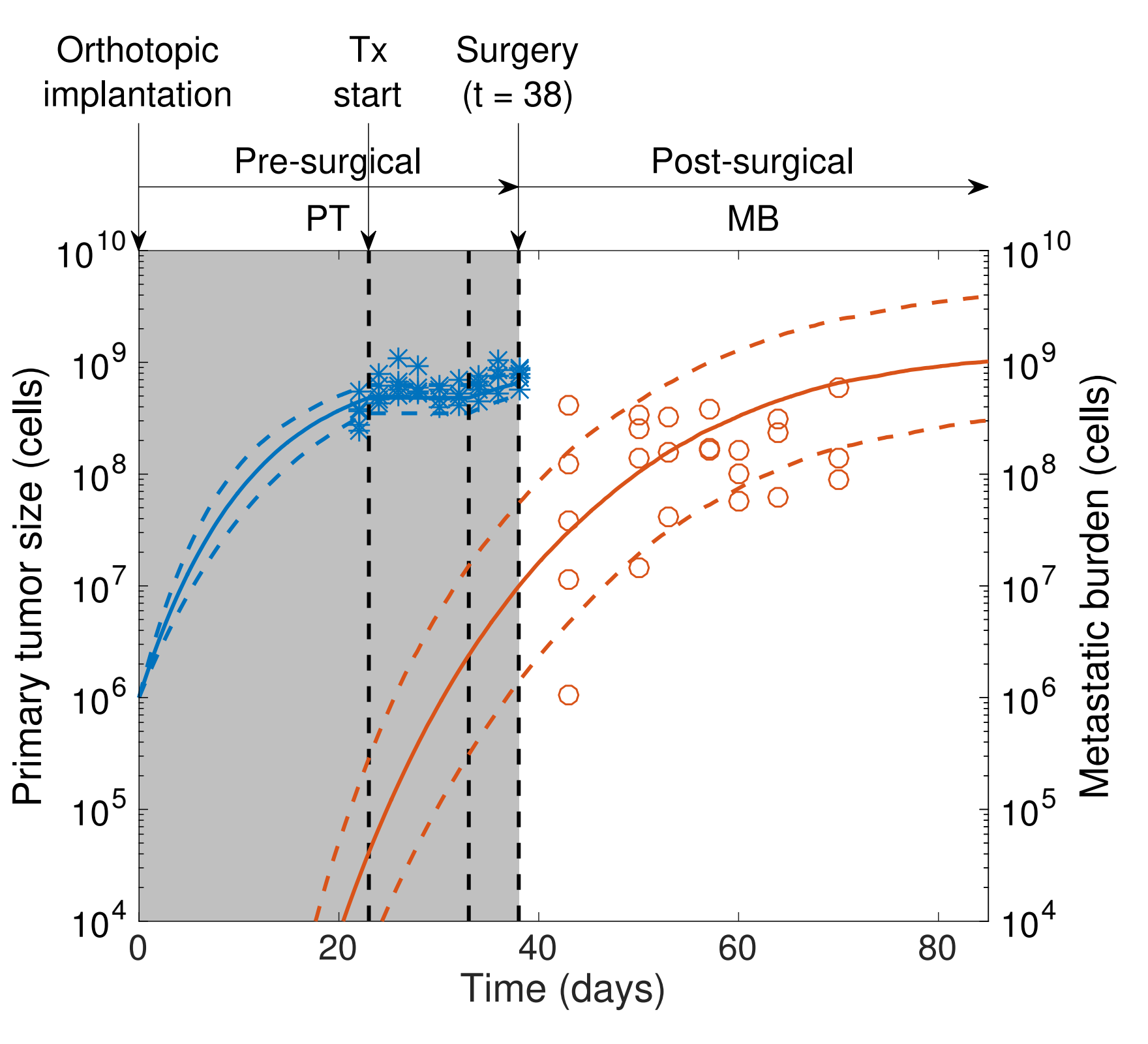

Population fit assuming no effect of treatment on metastasis

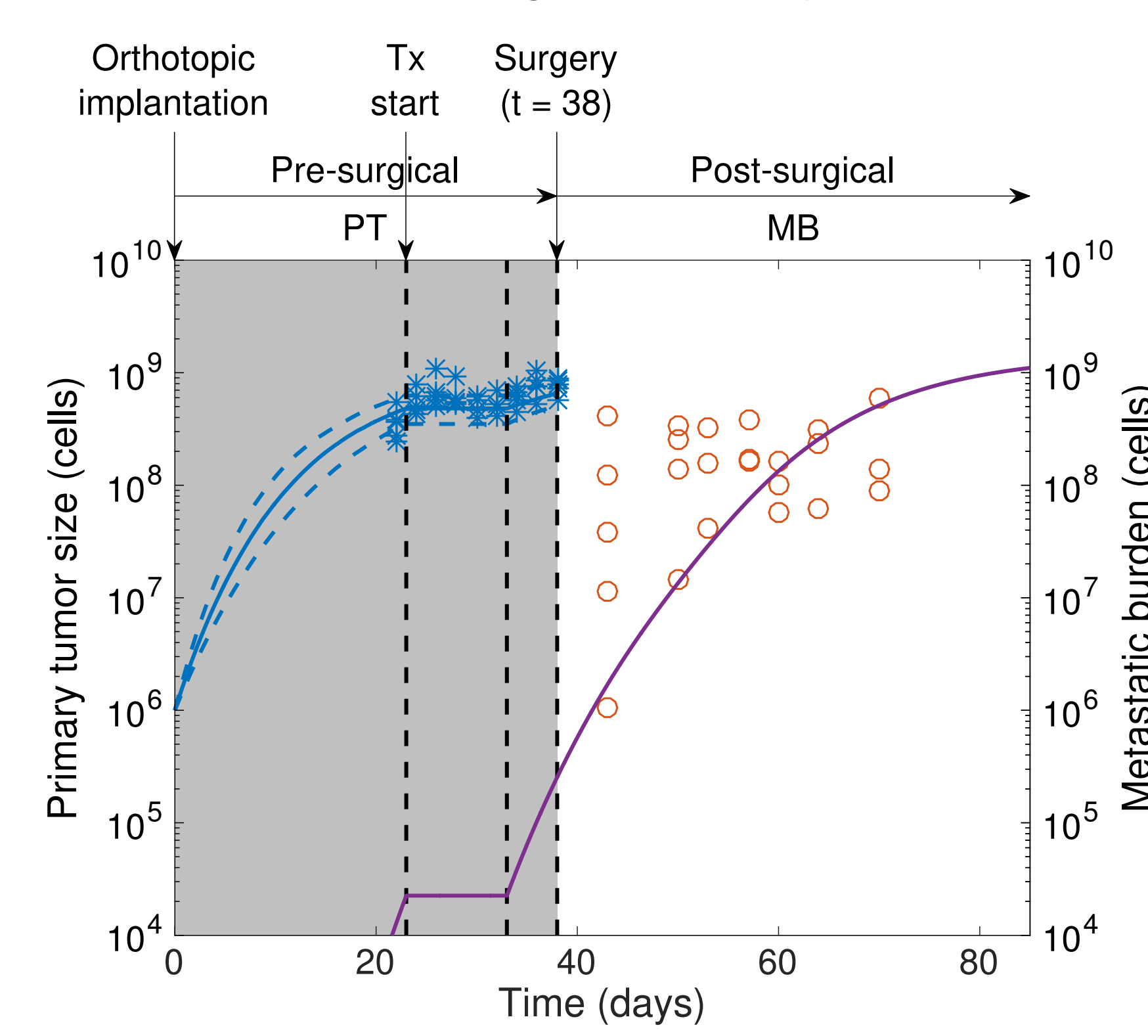

Simulation of treatment also on metastasis
Treatment acts differently on primary and secondary tumor growth
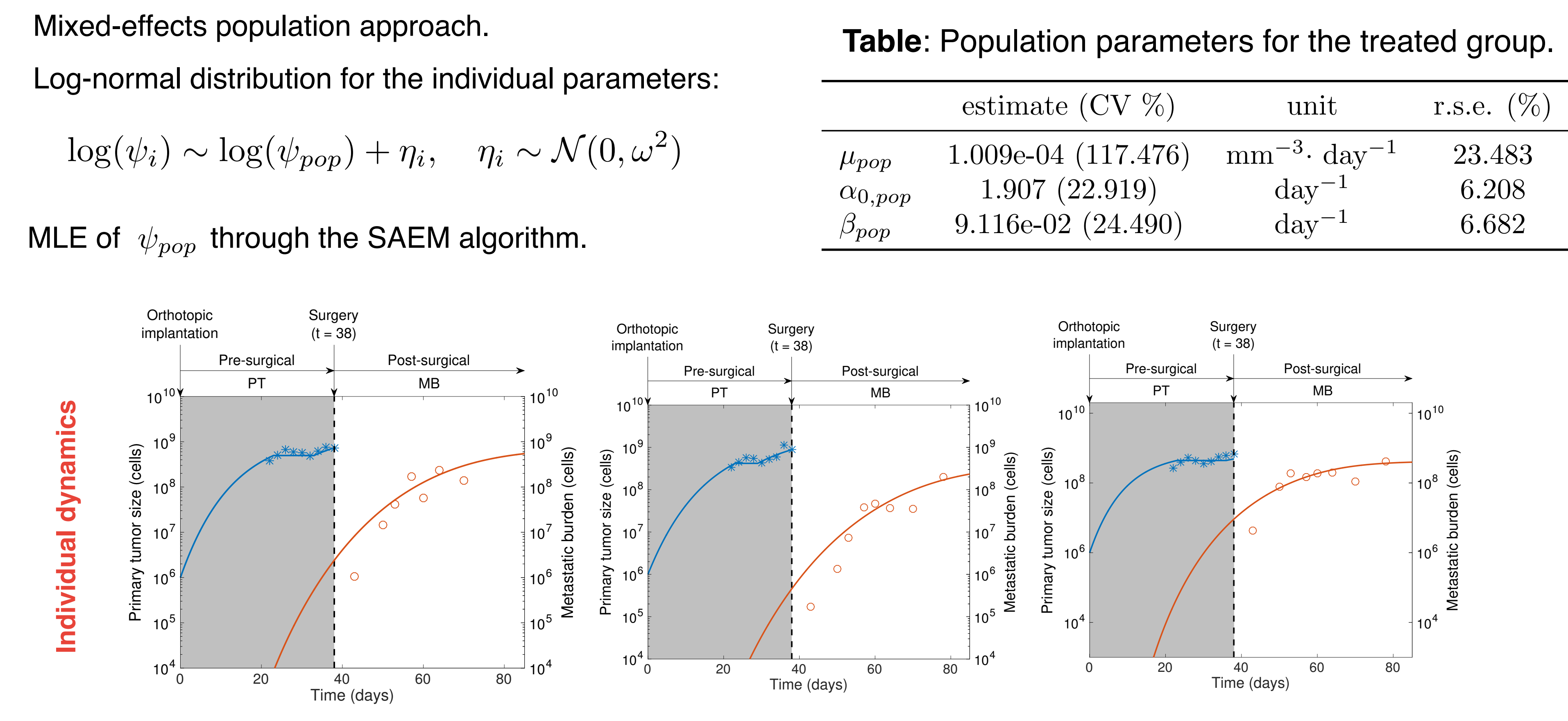

COVARIATES ANALYSIS

Dissemination rate

$d\left(V_{p}\right)=\mu V_{p}$

Size distribution of the metastases $\rho(t, v)$

$\int \partial_{t} \rho(t, v)+\partial_{v}(g(v) \rho(t, v))=0$ $\partial_{t} \rho(t, v)+\partial_{v}(g(v) \rho(t, v))=0$
$g\left(V_{0}\right) \rho\left(t, V_{0}\right)=d\left(V_{p}(t)\right)$ $\rho(0, v)=\rho^{0}$

Metastatic burden (total metastatic number of cells)

$$
M(t)=\int_{0}^{t} d\left(V_{p}(t-s)\right) V(s) d s
$$

\section{REFERENCES}

[1] Ebos, J. M. L., Mastri, M., Lee, C. R., Tracz, A., Hudson, J. M., Attwood, K., Cruz- Munoz, W. R., Jedeszko, C., Burns, P., and Kerbel, R. S. (2014). Neoadjuvant antiangiogenic therapy reveals contrasts in primary and metastatic tumor efficacy. EMBO Mol Med, 6(12):1561-1576

[2] Benzekry, S., Tracz, A., Mastri, M., Corbelli, R., Barbolosi, D., and Ebos, J. M. L. (2016). Modeling spontaneous metastasis following surgery: an in vivo-in silico approach. Cancer Res, 76(3):535-547.

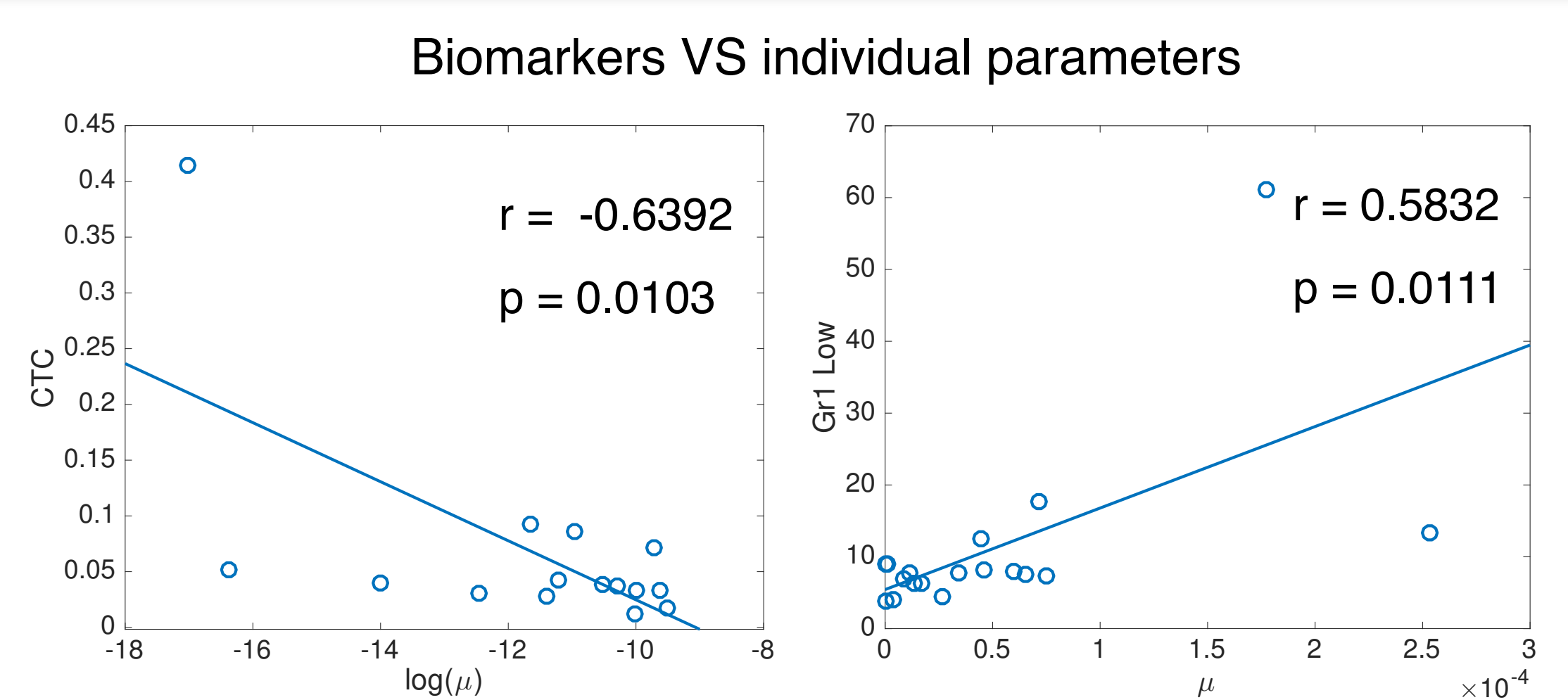

- Biomarkers can be included in the model as covariates in order to explain part of the variability in the individual parameters

$$
x_{i}: \text { individual covariate } \longrightarrow \log \left(\mu_{i}\right)=\log \left(\mu_{\text {pop }}\right)+\beta x_{i}+\eta_{i}, \quad \eta_{i} \sim \mathcal{N}\left(0, \omega^{2}\right)
$$

These results confirm a differential effect of sunitinib on primary (localized) tumors compared to secondary (metastatic) disease. Our results suggest that Ki67+/CD31+, CTCs and MDSCs measurements might help in personalized prediction of metastatic potential and thus aid in predicting benefit in overall survival for preoperative antiangiogenic treatments. 